\title{
Designing Frameworks for Authentic Equity in Science Teaching and Learning: Informal Learning Environments and Teacher Education for STEM
}

\author{
Jennifer D. Adams \\ Department of Chemistry and Werklund School of Education, \\ University of Calgary \\ Calgary, Alberta, $\mathrm{T}_{2} \mathrm{~N}_{3} \mathrm{C} 8$, Canada \\ jennifer.adamsı@ucalgary.ca
}

Received: 14 September 2020 | Revised: 12 November 2020 |

Accepted: 30 November 2020

\begin{abstract}
In order to advance authentic equity in science education, it is salient to have frameworks that allow educators and researchers to design learning environments, activities, and research agendas that centers students' strengths in order for them to achieve full participation in science. As such it is important to consider the social identities of science education stakeholders - teachers and students - in teacher education. However, as identity is complex, it requires research approaches that elucidate not only the nuances of teacher identity but also the complexities of science teaching and learning environments. This article describes a collaborative research project that aimed to unpack the relationship between teacher identity and learning to teach. It outlines the collaborative process of theory building that includes teacher participants and the research team and how the framework for teacher education emerged that considers the various aspects of designing equitable and liberatory science learning.
\end{abstract}

\section{Keywords}

science teacher identity - equity - informal learning environments - collaborative research - agency - critical issues 


\section{Introduction}

The United Nation's Sustainable Development Goals (SDG) all address socioscientific issues, which have both scientific and social etiologies and implications. Ensuring that we as a global collective meet these goals requires the active participation and engagement of citizens at all levels. From having knowledgeable voters to having scientists and policy makers who center planetary well-being in their activities and decision-making, it is important that any engagement with science has equity at its core.

Equity is a word often used in education, educational research, and philanthropy to describe initiatives aimed at diversity, inclusion, and general goodness towards marginalized people. A Merriam-Webster dictionary definition of equity is "fairness or justice in the way people are treated (n.d.)." Based on my work in science education, I define equity in science education as no existing statistical or descriptive barriers or differentials in achievement along demographic characteristics such as race, gender, ethnicity, socioeconomic status, and ability. This would also mean a broad representation of people in leadership and decision- and policy-making levels in STEM, in STEM teaching, and learning and research roles, and places of STEM education and practice would be visibly and ideologically reflective of this diversity. However, on the road to achieving this vision of equity, we would need to consider who are the most marginalized and how to transform the systemic barriers that maintain marginalization.

In the context of the SDG and maintaining an agenda of equity in science education worldwide, we need to identify who are the most marginalized in a given society: Marginalization could be determined by race; ethnicity; socioeconomic status; gender; ability; a host of social, political, and historical reasons; and contextual barriers to full participation in STEM. Because this paper is based on research in the United States, the marginalization that is described here is largely based on race and racial politics.

I extend the definition of equity to "authentic equity" in science education, meaning science teaching and learning that inspires all stakeholders, especially those from marginalized groups, to be true to who they are and what they bring into science and science education spaces. This entails both designing and fostering learning environments that encourage learners to leverage their own cultural resources to engage in science learning and valuing diverse contributions as collaborative resources for the co-production of scientific knowledge. This means embedding indigenous, traditional ecological, and land-based onto-epistemologies as an integral part of the knowledge ecologies 
and engaging students in critical socioscientific questions that address local and planetary well-being.

For teachers to create these spaces of authentic equity, it is critical that they experience science teacher education based on frameworks that allow them to empathize with diverse learners in ways that value their ways of knowing, with this being leveraged as a resource for active and meaningful engagement in science learning. Collaborative research is important in the advancement of these frameworks as it requires integrating diverse theoretical, methodological, experiential, and practitioner lenses to understand the complexities of science teaching and learning contexts. Teacher identity is an important construct in relation to authentic equity because it provides a framework for understanding the relationship between the social identities of the teachers and the social identities of their learners that is responsive to the perceptions of learners and related practices enacted based on those perceptions. Understanding teacher identity is also important for understanding the material aspects of learning to teach and teaching: how a teacher engages with the physical (e.g., lab equipment, specimens, and observation tools) and conceptual (e.g., science content, ideologies that shape science, and approaches to scientific inquiry and investigation) resources necessary for effective and meaningful science education.

In this paper I describe a research project that focused on teacher learning in informal environments involving teachers learning about their own identities in relation to their students and in relation to their learning environments and how critical considerations of all together are necessary to support authentic equitable science learning. Informal science learning environments (ISLEs) ${ }^{1}$ refer to informal science institutions such as natural history museums, science centers, zoos, botanical gardens, and aquaria. These also include environmental and nature centers and place-based, community-based learning. I center the collaborative research processes, both with the teacher participants and the research team, and how a framework for teacher education emerged that considers the various aspects of designing equitable and liberatory science learning. First, I briefly describe the relationship between teacher reform initiatives and science-rich ISLE s. This is followed with a discussion of how I developed an initial theoretical framework to connect teacher learning, teacher identity, and ISLE learning. The subsequent section outlines the research and analytical process, which is then rounded out with a description of an emergent theoretical and teacher learning framework. The paper ends with a discussion of the research and practical implications of the described approach to research and theory advancement.

1 I have also included other acronyms that are similar to ISLE at the end of the paper (e.g., ISE, ISI, ILE). 


\section{Informal Learning Environments and Teacher Learning}

In the United States, informal science institutions have a long history of working with K-12 education, both for school programs and teacher education (Adams, 2007). Much of this has been in the form of teacher professional development and school-related programs. It has also become more common for universities to partner with informal science institutions for teacher preparation through credit-bearing courses and professional development (Adams, Miele \& Powell, 2016). This corresponds with an increasing emphasis on inquiry-based and project-based learning and authentic science practices in science education. Therefore, integrating informal learning environments into teacher education is germane to contributing to educating science teachers for several reasons: ISLE s know how to engage learners, enhance teachers' understanding of science concepts, and provide teachers opportunities to learn about learners (Gupta, Adams, Keisel \& DeWitt, 2010; Gupta \& Adams, 2010; Melber \& Cox-Peterson, 2005).

With science education emphasizing more inquiry-based, culturally relevant, and authentic science engagement, integrating and leveraging the resources of ISLE s can play a critical role in improving science teacher education because the "emphasis on phenomena-rich learner-driven interactions resonates with the notion of inquiry underlying K-12 science education reform" (National Research Council, 2009, p. 194). In the United States, this is especially critical in urban areas where schools educate large percentages of students from racial and ethnic groups historically excluded from science majors and careers and are more likely to be lacking in qualified science teachers and effective science teaching and learning resources, such as adequate labs and updated experimental equipment (Darling-Hammond \& Sykes, 2003; Coble, Smith, \& Berry, 2009).

Learning to teach science is complex in that it includes understanding the content, discipline, and nature of science and the ways that learners understand, identify with, and/or engage in science; learning and enacting effective pedagogical approaches to teaching science; designing and nurturing effective learning environments; and developing the dispositions that relate to being a good teacher, such as enthusiasm, flexibility, perseverance, and positive professional identification (Davies et al., 2006; Darling-Hammond \& Sykes, 2003; Phillips, Finkelstein, \& Wever-Frerichs, 2007; Korthagen et al., 2006). To meet these challenges, new science teachers need opportunities to develop comprehensive professional teaching knowledge, which Wilson and Berne (1999) describe as "knowledge of subject matter, of individual students, of cultural differences across groups of students, of learning, and of pedagogy" (p. 177). Teacher education programs that center teacher agency and focus on 
the teacher-as-learner can address these challenges, as "the learning of student teachers is only meaningful and powerful when it is embedded in the experience of learning to teach" (Korthagen et al., 2006, p. 1030). Because ISLE s are learner-centered environments, teacher learning in collaboration with ISLE $\mathrm{s}$ can provide new teachers opportunities to observe learners and to practice science teaching in different contexts while focusing on learning to teach (Adams \& Gupta, 2017).

From prior research I found that teachers who participated in a museumbased professional development program reproduced museum-based displays and teaching practices in their physical classroom and the science projects that their students produced (Adams, 2007). Moreover, these teachers continued to seek ISLE-based resources for their professional growth and student learning (Gupta \& Adams, 2010). Therefore, integrating ISLE in teacher learning expands science teaching and learning opportunities both for teachers and for their students. Furthermore, a framework of identity highlights how teacher learning allows for the development of teacher identities that center equitable science learning.

\section{Developing a Framework for STEM Teacher Identity}

My initial identity framework was operationalized as teacher behaviors, beliefs and practices, and pedagogical knowledge that teachers develop during their teacher education and classroom practice (Moyer-Packenham et al., 2008). Teacher beliefs include beliefs about the ways students learn content, about who can and cannot learn, and about the nature of content and the best methods for teaching it; teacher behaviors and practices include what the teacher does in the classroom; and pedagogical knowledge refers to knowledge of teaching and learning, including knowledge of students' cognitive development, learning theories, and instructional approaches and strategies (ibid, p. 573). Initially, the research was based on the assumption that ISLE learning contexts provide the environments and experiences that promote teacher identities that ultimately lead to STEM achievement in underrepresented urban students (see Table 1). This study first examined the factors in teacher professional identity development that were believed to lead to positive student outcomes, although the student outcomes were not to be the subject of study in the project.

The initial teacher identity and learning framework that aligns the attributes of STEM teacher quality (Moyer-Packenham et al., 2008) with characteristics of ISLE learning (Adams \& Gupta, 2017; Gupta \& Adams, 2010) and how they could possibly influence student outcomes. 
Influence teacher identity in terms of
Possibly leading to student STEM outcomes
- Direct learning and/or teaching experiences with diverse learners in an ISE context;

- Focused on pedagogical content knowledge;

- Reflection on student learning;

- Connection of experience(s) to classroom and curriculum assessments through reflection and/or direct assessments;

- Learn from and work with ISE-based faculty and staff.
- Teacher behaviors and practices;

- Teacher beliefs;

- Pedagogical knowledge.
- Motivation and engagement with STEM;

- Achievement in STEM;

- Pursuit of STEM interests and careers.

\subsection{Moving Towards a Sociocultural-Ecological Approach to Teacher Identity and Learning}

At the inception of this study, the informal science education (ISE) field was moving towards ecological approaches for understanding learning in and across informal contexts (National Research Council, 2009). This perspective allowed us to examine the relationships between people and the different places that support STEM learning. This framework was also salient for examining the relationship between ISLE and teacher education because learning to teach occurs in a social milieu across places and time. However, the focus of existing research on teacher learning has largely been on university-based coursework and the classroom, leaving out many of the other places where teachers learn to teach, including ISLE contexts.

The Learning Science in Informal Environments (National Research Council, 2009) framework presents three cross-cutting lenses that describe how people learn science in informal environments: people, places and culture. The ecological approach also complements sociocultural approaches in that they consider how the contexts in which teachers learn to teach shape their science teaching identities. The ecological framework recognizes that "identity development and elaboration are linked to affective and motivational issues that catalyze learning" (National Research Council, 20o9, p. 41). The initial framework for research described teaching identities in terms of four attributes that teachers develop across places and time: behaviors, practices, beliefs, and 
pedagogical knowledge (see Table 1). The research initially sought to describe or revise this framework in the following terms: in what ways these characteristics develop in ISLE-based experiences, in what ways can these characteristics be described for ISLE-educated teachers, and how evidence of ISLE learning, through these characteristics, shows up in the classroom.

The LSIE framework (National Research Council, 2009) includes six strands that describe the goals and practices of science learning in informal environments. Table 2 demonstrates how the LSIE learning strands connect with the teacher identity framework described in Table 1. Teachers learning to teach in ISLE contexts not only experience the strands as learners but also are able to reflect on their ISLE learning experiences and think about how they apply to classroom teaching.

TABLE 2 Mapping of teacher identity onto the LSIE learning strands

\begin{tabular}{|c|c|c|c|}
\hline $\begin{array}{l}\text { Teache } \\
\text { is }\end{array}$ & Which is defined as & $\begin{array}{l}\text { Collects with } \\
\text { ILE learning } \\
\text { strands }\end{array}$ & $\begin{array}{l}\text { LSIE learning } \\
\text { strands }\end{array}$ \\
\hline Beliefs & $\begin{array}{l}\text { Beliefs about: } \\
\text { The ways students learn content; } \\
\text { Who can and cannot learn science; } \\
\text { The nature of the content and the } \\
\text { best methods for teaching it. }\end{array}$ & $\begin{array}{l}\text { Strand } 2 \\
\text { Strand } 3 \\
\text { Strand } 5 \\
\text { Strand } 6\end{array}$ & $\begin{array}{l}\text { 1. Developing } \\
\text { interest in science } \\
\text { 2. Understanding } \\
\text { science knowledge } \\
\text { 3. Engaging } \\
\text { in scientific } \\
\text { reasoning }\end{array}$ \\
\hline
\end{tabular}

\begin{tabular}{llll}
$\begin{array}{l}\text { Behaviors and } \\
\text { practices }\end{array}$ & $\begin{array}{l}\text { The learning environment the } \\
\text { teacher designs/creates/nurtures; } \\
\text { The moves a teacher makes in the } \\
\text { classroom. }\end{array}$ & $\begin{array}{l}\text { Strand } 1 \\
\text { Strand } 2 \\
\text { Strand } 3 \\
\text { Strand } 4\end{array}$ & $\begin{array}{c}\text { 4. Reflecting on } \\
\text { science }\end{array}$ \\
\hline $\begin{array}{l}\text { Pedagogical } \\
\text { knowledge }\end{array}$ & $\begin{array}{l}\text { Knowledge of: } \\
\text { Teaching and learning; } \\
\text { Students' cognitive development, } \\
\text { learning theories, and instructional } \\
\text { approaches and strategies. }\end{array}$ & $\begin{array}{l}\text { Strand } 1 \\
\text { Strand } 2\end{array}$ & $\begin{array}{l}\text { Strand } 3 \\
\text { Strand } 6\end{array}$ \\
\end{tabular}




\subsection{Sociocultural View of Learning}

The theoretical underpinnings of this research were guided by a sociocultural view of learning. People make meaning of their world and develop behaviors, beliefs, and practices through participation in various cultures, which could be described as the social practices in a given context (Stetsenko, 2011; Hodkinson, Biesta, \& James, 2008). Although learning contexts (e.g., the classroom, museum, or other sites) may have clear boundaries, the cultures that develop at given sites have porous boundaries and are often influenced by people/learners moving between multiple sites (Hodkinson et al., 2008; Seiler \& Elmesky, 2005). Bourdieu's construct of fields is useful for describing how culture developed in one site (or field) can be enacted in other fields (Sewell, 1992; Hodkinson et al., 2008). Hodkinson, Biesta, and James (2008) note that "location and resources of the learning sites ... are not neutral, but enable some approaches and attitudes, and constrain or prevent others" (p. 29). This notion is useful for thinking about the identities that teachers develop while learning to teach and teaching in different contexts. It also describes some of the other things that influence learning, such as the positions, dispositions, and actions of the students, faculty, and staff; the time participants (e.g., teachers, faculty, and ISLE staff) spend together in a particular culture, including the interrelationships they develop; and the wider range of cultures and social contexts in which they engage (ibid, p. 29). Thus, rather than passively acquiring knowledge of teaching theory and methods, teachers are actively engaging in and producing culture as they learn and understand STEM content, teaching, and learning and are developing corresponding professional teaching attributes. It is in these social/learning contexts that teachers develop the beliefs and practices, behaviors, and pedagogical knowledge that define their STEM teaching praxis. Therefore, learning to teach is an ongoing process of producing culture and contributing to the collaborative practices of the STEM teaching and learning community.

\section{$4 \quad$ Researching Urban STEM Teacher Learning and Identity}

In New York City and the larger country of the United States of America, there is a longstanding issue of inequity in science. Black, Latiñes, ${ }^{2}$ and Indigenous

2 There have been recent discussions about a gender neutral Spanish sounding term to describe people who have this social identity: https://www.dailykos.com/stories/2019/10/ 8/189109o/-The-Problem-with-Latinx and https://twitter.com/LemieuxLGM/status/ 1293261579006271488 . 
people are largely underrepresented in the science fields (e.g., Hurtado et al., 2010). This issue has also been identified in other settler-colonial and colonial contexts such as Canada and the United Kingdom (e.g., Syed \& Chemers, 2011). To address this issue, Informal Learning Environments and Teacher Education for STEM (ILETES), an integrated research and education project funded by the United States National Science Foundation, focused on teacher identity and teacher education in informal settings. The project was situated at a diverse, urban, 4-year, non-residential college in the largest public university system in the United States. The initial and primary goals of the project were to use an identity lens to learn how teachers experience formal-informal collaborations in their teacher education and how these experiences transfer into classroom practice in urban high-needs schools. In the United States, according to the No Child Left Behind Act of 2001, high-needs schools are schools that serve communities with higher poverty rates, have high percentages of teacher who are teaching out of field, and have high teacher vacancy and teacher turnover rates. Most high-needs schools are located in urban or rural areas.

The research used participatory and dialogic research methodologies and interpretive analyses to ensure that the participants' perspectives were accurately represented in the data analysis and that participants would be empowered to catalyze improvements in science teaching and learning (Adams, in press; Adams \& Siry, 2020). There were two main phases of the research. In Phase 1, teachers who took ISLE-integrated courses during their teacher education were invited to participate in an interview lasting about 45 minutes to an hour. These interviews were designed to be dialogic: Members of the research team all had experience with classroom teaching and were therefore able to engage research participants in a discussion about their teacher learning, classroom practices, and student engagement. They were also prompted to reflect on their own identities through questions that asked them to describe themselves as teachers. Thirty teachers participated in the interviews. Phase 2 of the research was designed to be a longitudinal study of new teachers (within their first 5 years of practice) who also took ISLE-integrated teacher learning courses. Over 3 years, these teachers participated in a group called Collaborative Teacher Inquiry Around Informal Science Learning and Science Teaching in Urban Classrooms, which became an important space for these teachers to talk about science teaching and learning in their contexts. A cogenerative dialogue approach was used to facilitate group discussions where the teachers shared their experiences with teaching and ISE and used this to develop new meanings and solutions in equitable science teaching (Martin, 2006). Several of the teachers identified as Afro-Caribbean, African 
American, or Latiñes, and this showed up in discussions: being a teacher of color teaching students of color.

\subsection{Collaborative Analysis}

Key to engaging with this research was the collaborative nature of the research team. While the initial framework of identity was outlined as above, we struggled to articulate a clear definition addressing the questions of identity formation and especially considering the social constructs of identity in relation to developing a professional/teaching identity. As such, we wanted to attend to the complexities of identity and identity development. First, that identity is relational and develops and shifts with encounters and engagements with the social, material, and even ephemeral factors of social life. Second, describing a teacher identity is not possible without describing the relationship between the teacher and students, which includes attending to the social identities of both in relation to each other. Third, we all shared a critical lens and wanted to ensure that issues of power in relation race, gender, socioeconomic status, and ability were all in our descriptions of teacher identity and practice. What follows is our discussions about the nature of teacher identity, including interrogating existing literature about teacher identity and other literature that describes aspects of identity that we thought were important in consideration of equitable science education: subjectivity, agency, and identity.

\subsection{Subjectivity, Agency, and Identity}

While there is a cultural notion of the image of a teacher, there is not the same fixed idea of how to be a teacher, because for a teacher the context is always shifting and changing; as such, teacher identity is not fixed but rather an ongoing production that is never fully complete (Avraamidou, 2014). We thought about the aspects of teacher identity that are relatively stable, such as race, gender, ethnicity, but these are not described as "teacher" identities, but rather social identities that saliently influence teacher identities. We found two constructs that seemed to be critical in describing how social identities influence teacher identity development in the process of learning to teach and in teaching: subjectivity and agency.

Subjectivity describes the socially constructed and contested identity: the one that is constantly being made and remade. Subjectivity is constantly in flux and responsive to daily lived experiences:

the conscious and unconscious thoughts and emotions of the individual, her sense of herself, and her ways of understanding her relation to the world ... [It] is not stable but is constructed in relationships in others 
and in everyday practices - ongoing process of "becoming" rather than merely "being" in the world.

JACKSON \& MAZZEI, 2O11, p. 53

Therefore, being a teacher is always becoming a teacher: The subjective teacher is always in relation to other subjectivities - those of their students first and foremost and of other social beings with whom they engage on a daily basis, "social structures and process that shape our subjectivities are situated within discursive fields where language, social institutions, subjectivity, and power exist, intersect, and produce competing ways of giving meaning to and constructing subjectivity" (Jackson, 2001, p. 386).

As critical researchers we are fully aware of structural inequities and how this shapes our subjectivities. For example, the ILETES teachers often described the ways that they were positioned by their White counterparts and how this led to them feeling devalued, "[he questioned and downplayed my input] even though I am more experienced and have a masters when at the time he didn't." Racialized teachers and students are subjected to overt racism and more subtle microaggressions $^{3}$ on a frequent basis and this shapes their experiences and identities in science education. However, as activist-minded scholars we are also aware of the strength of the individual/collective towards societal transformation, even if that scope of that transformation is the immediate classroom; ILETES teachers also often noted how the research group supported and inspired them to center equity and advance their science teaching practices. The individual/collective implies that in the context of identity development, individuals change as they engage with the collective while sharing experiences and developing shared understandings about the complexity of social life - in this case science teaching and learning in a diverse, urban context. We found that the construct of agency was important in advancing this notion, where in a collective, agency is "radically conditioned" and allows teachers to "reflexively and critically examine their conditions of possibility" and "both subvert and eclipse the powers that act on them and which they act" (Davies, 2006, p. 426). During ILETES dialogues the teachers expressed awareness of race how this influenced the ways they were perceived, their students were perceived, as well as their responses and moves as a teacher in different situations. For example, one teacher's experience and expanded awareness that

3 Racial microaggressions are brief and commonplace daily verbal, behavioral, and environmental indignities, whether intentional or unintentional, that communicate hostile, derogatory, or negative racial slights and insults to the target person or group (Sue, Capodilupo, Torino, Bucceri, Holder, Nadal, \& Esquilin, 2007, p. 273). 
her Black students were less prepared in science than their wealthier and White counterparts prompted her to create a science enrichment program in her community. With agency, teachers are able to individually/collectively devise ways to subvert the inadequate teaching conditions that often plague urban schools and design transformative science education opportunities for themselves and their students. Agency allows teachers to access and appropriate resources at hand to meet goals (Adams \& Gupta, 2017) and provides a salient lens for examining how teachers use informal science, as physical and conceptual resources, to enact meaningful science teaching and counter negative and persistent storylines (Nasir et al., 2013) about students/people of color and schooling.

Central to this idea is identity: keeping the questions of "who is the 'I' who teaches" and "who are my learners" central to the conversation, as one teacher in the collaborative mentioned in her reflection during her pre-service teacher education:

"Who am I going to be as a science teacher? What am I going to be like?" But I think I started with myself first, my own identity. "Who am I" and "What are my experiences?" and "How am I going to translate that into the classroom?" ... I think to be successful you just have to know yourself first and then translate that into whatever it is that you are doing.

Whether through research or through learning to teach, forefronting the social in relation to the material aspects of learning to teach and teaching creates the conceptual space to allow for the development of teaching identities - beliefs, behaviors and practices, and pedagogical knowledge - that center racially, gender, ability, and socioeconomically diverse learners. Further it allows us to rehumanize learning to teach and teaching, centering teachers in the interactions between learners as unique human beings rather than emphasizing policies and standards that are far too often removed from the lived experiences of teachers and students. Furthermore, with science teaching being resource dependent, whether in the laboratory, classroom, or informal spaces, the interaction with the material is important for describing science teacher identity: how teachers use these materials and, more importantly, how they adapt and transform these materials to meet the needs of their learners.

The interaction between subjectivity/agency is recursive. As identities may be culturally, socially, or institutionally assigned (Weedon, 2004), awareness of one's own subjectivities, including the ways that existing societal structures influence these subjectivities, affords a sense of agency because knowledge is power. Being a part of a collective who are also becoming critically aware 
of these structures affords a sense of transformative agency towards societal change, including changes in science teaching and learning. This is a part of a process of learning in which the nexus is identity. Learning also means to be able to adapt, appropriate, and, more importantly, recreate new actions from existing resources to meet goals. As one is always learning and creating, identity is always changing. Therefore, this emerging framework allowed us to consider teacher identity as the ongoing interactions between subjectivity, agency, and identity through the cultural actions of learning to teach and teaching. A teacher's expanded awareness of self-as-teacher, self-as-learner (teachers' subjectivities), and students' subjectivities that happen in ongoing teacher learnings both shape teaching identity and fosters agency.

These discussions and corresponding readings did not lead us to a unified definition of identity but rather allowed us to think more expansively about the nature of teacher identity - those things that shape and enable and also truncate teacher identity - and the way this relates to how a teacher transfers their own teacher learning experiences into practice.

\subsection{Moving Towards a Diffractive Analysis}

At the time of the interviews, we were collectively reading Thinking With Theory in Qualitative Research: Viewing Data Across Multiple Perspectives (Jackson \& Mazzei, 2011), and this confirmed the direction in which we were headed, allowing to use our own lens to interrogate the data and come up with diverse findings in order to deepen our perspectives on teacher identity and teaching. We also realized that our identities as researchers, former classroom teachers, informal science and museum educators, and researchers, and our own social identities, influenced how we individually and collectively interrogated the data. Our own lens, the theories that we each grappled with in our own work outside of the ILETES project influenced what we were seeing what stood out to us - in the data. As such we decided to engage in a diffractive analysis of the data: "A diffractive reading of data through multiple theoretical insights moves qualitative analysis away from habitual normative readings (e.g., coding) toward a diffractive reading that spreads thought and meaning in unpredictable and productive emergences" (Mazzei, 2014, p. 742). Although the initial data collection tools were framed around questions of identity and practice, the diffractive analysis process allowed us to reveal four distinct and salient themes in relation to teacher identity and practice, especially in relation to teaching diverse learners.

Diffractive Insights. Our wonderings through different notions about the nature of teacher identity led us to use our own critical lens and corresponding analytical questions to interrogate the data. This allowed us to move towards a 
more circuitous and reiterative process of data analysis that was both reflective of social life and the nature of identity as we collectively understood it. There were four of us who were a part of the research team. As the PI, the diffractive approach allowed me to afford a greater sense of agency to my co-researchers, and this contributed to a richer reading of the data than would have been possible using a unified theory. Through our diffractive analysis we highlighted the ways that anti-Blackness presented in science classrooms in the ways that teachers described their students and explained why they taught in the ways that they did. We also have been able to further theorize and highlight the ways that unexamined Whiteness structure teacher identity and enactment for White teachers in relation to their students of color. We also elucidated the political activities of teachers in terms of their perceptions of students and decisions that they make in the classroom (Das, Strong, McCullough \& Adams, 2020). We are continuing to build theories in these areas as we individually and collectively revisit the data and strengthen the definitions and descriptions in the analytic and writing process.

\subsection{Critical Agentic Bricoleur: Teacher Identity and Learning Framework}

Taking all of these findings together in a big picture view of the research, I propose an emergent framework for teacher learning and practice. This framework is not meant to essentialize a teacher identity, but rather propose a framework for learning how to think like a critically aware, equity-minded, and social justice-oriented teacher. This framework first started by thinking about the individual teachers in the collaborative group. They had different social identities and although they taught in the same public school system, each of their classrooms was vastly different. They converged in how they viewed ISE as a creative way to advance equitable science learning, but the ways that they adapted ISE frameworks and resources were very different, albeit influenced by each other's practices. For them ISE meant creating a space where students could engage in science learning in meaningful ways and at their own pace; self-directed and collaborative learning; project-based, hands-on, and creative learning; and helping to develop learners who love science and see the importance of science in their daily lives. I started to think of them as archetypes, because one of the participants used that word to describe how I was describing them (Adams, in press), but subsequently moved to a more comprehensive framework to describe how they thought about their teaching enactments in relation to the initial teacher identity framework.

Authentic Equity: Critical Agentic Bricoleur ( Steinberg and Joe Kincheloe (2010) forwarded theoretical and methodological bricolage as a "mélange of theories and their interactions" (p. 140) which 
allows critical theorists and researchers to "gain new understandings of how power operates, and in the process incorporate groups who had been previously excluded by their race, class, gender, sexuality or geographical place" (p. 141). Through accessing different resources, including expanded critical awareness of issues of social identities in relation to power and privilege in science education, the teachers in the collaborative engaged in a critical bricolage where learning to teach and adapt ISE resources and practices to meet the needs of their classrooms and identities as teachers. Importantly, the teachers became more attuned to issues of inequity and this awareness moved to the center of who they are as teachers and correspondingly how they taught science. "Polyphonic bricolage" is an anthropological term use to describe the process of cultural continuity as people adapt new resources and environments to create a new culture that resonates with their identities (Schmidt, 2008). As the teachers in the collaborative encountered new resources, places, and pedagogical approaches for science teaching they individually and collectively created new structures for science teaching, thus expanding opportunities for science learning for diverse learners (Adams, in press).

Based on my analysis and understanding of how the teachers' professional and social identities - their subjectivities and those of their students influenced how they adapted and transformed the resources that they encountered, including the idea of ISE, I forwarded the idea of critical agentic bricoleur (Adams, 2019; Adams, 2018). CAB is "the ongoing augmenting and adapting [of] resources at hand into new science teaching and learning engagements with special attention to attenuating the challenges faced by students [historically] marginalized from science," with new science engagements also including "the incorporating of cultures, [including] youths' language and ways of being in social spaces ... into teaching and learning towards student engagement and success (Adams, 2019)." Being and becoming а САВ considers "the sociomaterial entanglements that constitute sтем teaching and learning - the intersections of physical and digital resources and spaces, bodies, languages, and cultures in the conceptual science classroom" (Adams, 2019).

In this framework for research, ongoing learning and teacher learning and professional development affords a space for the development of teachers with a critically conscious lens as they focus on creating equitable science teaching and learning experiences for their students, especially for those most marginalized and historically oppressed. This framework centers reflexive questions: Who is the "I" who teaches science? Who are the "they" who are my science learners? What are the overarching historical, political, and social factors that shape learning experiences for me, my students and the larger societal context in which the school and surrounding community is situated? Figure 1 illustrates the notion of $\mathrm{CAB}$. 


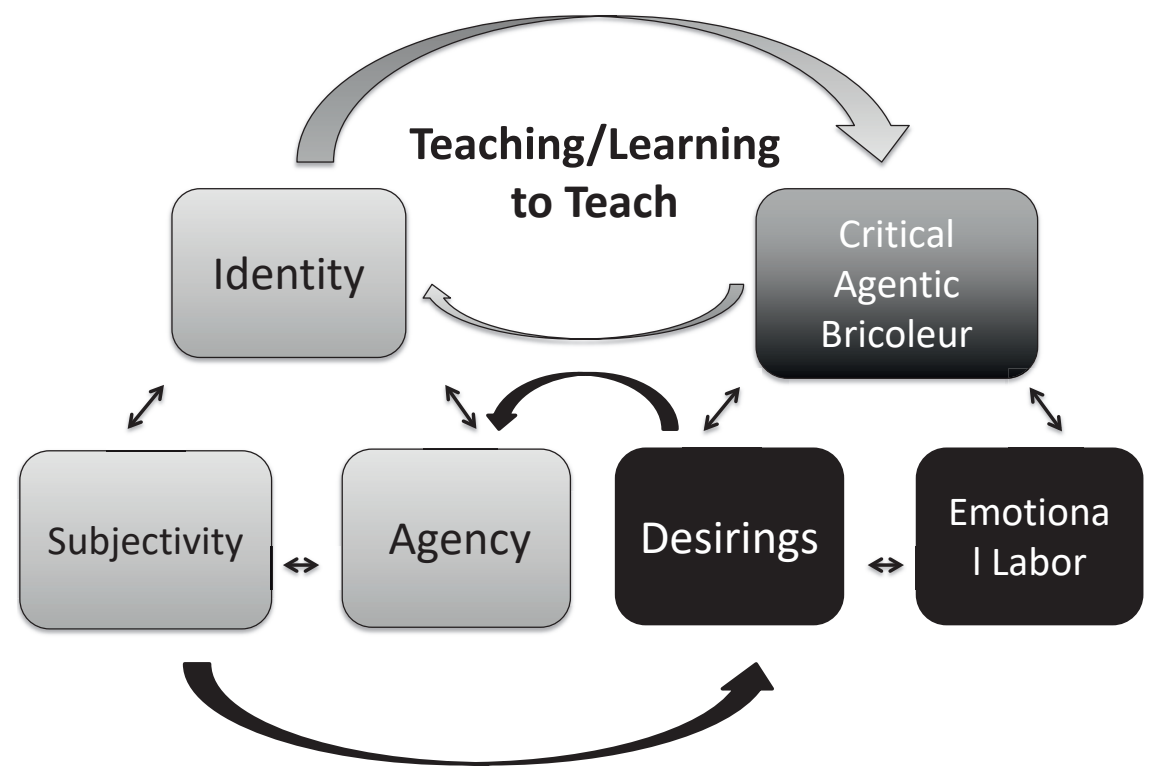

FIGURE 1 Critical Agentic Bricoleur

When teachers develop a critical consciousness as they engage in learning to teach and teaching, both their subjectivities and those of their students become more conscious and central to who they are and the decisions that they make in the classroom. This creates a reflexive and critical examination of the possibilities of science teaching and learning in their classroom, despite the external/societal structures that limit the learning and social possibilities for them and their students. Their subjectivities also produce their "desirings" (what a person wants or longs for); the kinds of learning opportunities and experiences that they strive to create for their students, especially their socially and ability diverse learners. Their agency lies in their bricolage - adapting and transforming resources, including the conceptual notion of informal science learning, for transformative and liberatory science learning experiences for their students. But this is not without challenges, which include the emotional labor of being a Black or Latiñes teacher with a heightened awareness of issues of race in science education. For one teacher in the collaborative, this was also intersected with learning differences. For teachers who are not people of color, this could also include the labor of becoming increasingly aware of racial privilege and subverting the Whiteness that structures science education for their students and colleagues of color. What follows are representative quotes that illustrate the characteristics of the critical awareness of science education inequities that emerged in the collaborative and shaped the ideas around the 
collaborative teachers' purposes and approaches towards authentic equity in their classrooms.

\subsection{Bricoleur of Voice and Visibility}

The bricoleur of voice and visibility recognizes the spaces where marginalized students are made visible and where they are silenced. As such, this bricoleur creates space for equity in voice and visibility, "I am their voice, because if I am not their voice, who is going to be their voice?" This means recognizing where students are silenced and made invisible in the classroom and within schools:

We were talking about how the students of color, they don't raise their hands as much and how their counterparts, the White students, they raise their hands all of the time ... I have to actively like, tease out these issues, which I don't mind.

I realize like when our whole grant meeting when we [colleagues at the school] talk about students' achievements of students who have challenges, I realize that I just always present the students of color ... "do you notice they need glasses, they are squinting," or "this student in struggling" [colleague would respond] "yeah, they are struggling in my class too." And I'm like, “why didn't you raise the question?” ... it's almost like it's okay if they are struggling.

This bricoleur works to ensure that her students are visible both in and out of the classroom. She makes in a point to call on students of color so that the other students know that they know the answers and that they are just as smart and capable in science as the White students. She also ensures that the struggling students get the help that they need to be successful not only in science but also in their other classes. Within her classroom, she creates learning experiences that allow her students, especially those who are most marginalized, to experience agency in science learning through assigning positive and visible roles, such as group leader in collaborative activities.

\subsection{Bricoleur of Trust and Communication}

The bricoleur of trust and communication asks, "What is our role as educators? What are the skills that we recommend our students need and how are we going to give them those skills? That's the question that we should be asking, you know?" This bricoleur centers trust in the classroom between themselves and their students and between students through creating a learning environment where students learn from and trust each other in that process, because learning is risky and requires a certain degree of vulnerability: 
I treat every kid that comes into my class, I have a dialogue with them. I know them. I meet them at the door and I greet them And at that instant, whatever, [however] they choose to respond with me ... I [will] know the student is either having an issue with something and I got to find out ... I have to address that issue and get rid of that distraction and fix that issue ... then the rest of my class becomes smooth and that student buys in. Because they know I care. They know they can talk to me.

Through ongoing dialogues with students, this bricoleur creates spaces where it is safe for students to use their own individual/collective cultural resources in learning, including kinesthetic, linguistic, and intellectual resources. For example, the bricoleur incorporates students' ways of communicating in and out of the classroom: One bricoleur used WhatsApp to create a learning culture that intersected their classroom, community, and digital spaces, which afforded their learners agency in shaping the direction of the learning interactions and positive identities around school learning, science, and academic success (Adams, 2019).

\subsection{Bricoleur of Experiences and Exposure}

The bricoleur of experiences and exposure views science as a way of expanding students' lived experiences and adding enrichment to the standardized subjects. This bricoleur resists and subverts administrative constraints while advocating for meaningful learning for their students that goes beyond the rote learning that is often privileged in standards-oriented schools and classrooms. This bricoleur extends science learning beyond the classroom through engagements with the science community, especially those that are reflective of the students' social identities, both within and outside of the local community, for example, attending science-themed seminars and conferences at the local college. This allows them to imagine and create diverse identities around science:

I think when I expose my students to different things, they feel smart, they feel like, and it's not necessarily because "I'm Black or I'm White,' but they just know that they are smart. Like, they go into a room and now it really doesn't matter who is there. They're willing to take risks; they're willing to get up and ask questions.

For this bricoleur, it is important that their students feel like they not only belong in science spaces, but also can be equal and valued participants to any discussions about science: "You are young [middle school] and you are here at 
a college. A college! And you are learning about this amazing scientific stuff ... real science ... they gain a lot of confidence through that."

\subsection{Bricoleur of Equity and Imagination}

This bricoleur designs learning to attenuate inequities in science teaching and learning and creatively uses resources at hand, both conceptual and material, to create innovative, engaging, meaningful, and relevant science learning both for students in the school and students in the community who might not have access to enriched science learning,

So, based on my experience in [affluent middle school], my experience at [charter school in lower income Black community], like it was too many gaps. Like the children at [affluent school], they [were] on it. They had more exposure to science, all of that! I remember last year I did an intro lesson on cells and my children [in the charter school], sixth graders, they had no clue what cells were. I was like, "this has to be a prank right now" ... so, I decided to start this Saturday program in [the charter school community] ... I am personally funding it ... I wanted children to have more exposure to science ... I am passionate about it.

This bricoleur extended science teaching and learning to the community in order to attenuate what she viewed as a history of inadequate science learning in the schools. She desired to do "cool science classes," but also realized that her school lacked advanced science courses such as chemistry and physics. Her desirings for her students include building their confidence in science, exposing them to expanded science learning, and for her "children" to have access to the same things that the students had in the affluent school. Because it was challenging to do these things within the existing structure of the charter school, she created an enriched science learning program in a local library to afford the children in her community the science skills and content knowledge that they were lacking in order to pursue more advanced science classes.

To reiterate, these are not meant as essentializing identities but meant to offer snapshots of ways of being in the classroom that support equitable science learning. It allows us a window into what drives the decisions of critically oriented teachers in the science classroom and what drives teachers' decisions in creating equitable learning environments for their most marginalized students. For teachers and teacher educators, it is about thinking of frameworks a critical social identity-centered way to think about teaching decision-making with the social identities of students in mind. These frameworks of teacher learning could be coupled with approaches to designing learning environments 
that are transdisciplinary and transformative in that they situate learners as active agents in investigating scientific issues that directly affect them towards improving their lives and their communities (Adams, Kim \& Das, 2020; Strong, Adams, Bellino, Pieroni, Stoops \& Das, 2016).

In the United States, issues of race as well as other social issues relating to class, gender, and ability are at the forefront of education. However, even with these issues very present in educational research and discourse and in the media, there is still a long way to go toward equitable science teaching and learning. ISE needs to go beyond being viewed solely as a resource for science teaching and learning and move toward a critical and adaptive approach: "Here are the resources. Who are your students and how do you think you will adapt and use them?" ISE, if integrated into formal curricula and schooling with a critical framework in mind, could offer spaces to begin to not only address social inequities in education but also work towards developing science teaching and learning practices that engage all learners. As such, it is critical that different countries consider the social equities that exist, how these inequities present in education, and the ways that research, teaching, and learning in ISLE s could help to address these issues. For example, modeling is often a way of teaching teachers to teach in informal learning environments. Allowing teachers to reflect on their own subjectivities in society in relation to being a learner may allow them to begin to empathize with the diverse learners in their classrooms. It is also important to be deliberate about presenting and discussing systemic inequities as they are experienced by the most marginalized students. These discussions should lead to how best to support these learners, not from a deficit or lacking perspective, but how diverse learners - racially, culturally, ethnically, ability, gender, and others - can be valued and celebrated in science teaching and learning contexts: How can we leverage what students know and their ways of being in the classroom towards equitable science teaching, learning, and being for all?

\section{Abbreviations}

СAB Critical Agentic Bricoleur

ILES Informal Learning Environments

ILETES Informal Learning Environments and Teacher Education for STEM 
ISE Informal Science Education

ISLE Informal Science Learning Environments

LSIE Learning Science in Informal Environments

SDG Sustainable Development Goals

Stem Science, Technology, Engineering and Mathematics

\section{Acknowledgements}

I would like to acknowledge Atasi Das, Susan McCullough, and LaToya Strong for engaging in the collaborative research process and the ILETES teacher collaborative for their creativity, insights, and active participation in the science teaching, learning, and research process.

\section{Funding}

This research was funded by the National Science Foundation, US. (AISL \#1254075)

\section{About the Author}

Jennifer D. Adams is a Tier 2 Canada Research Chair of Creativity and STEM and Associate Professor at The University of Calgary where she holds a dual appointment in the Department of Chemistry and Werklund School of Education. She uses critical, decolonial and sociocultural approaches to research and address issues of diversifying STEM and STEM education.

\section{References}

Adams, J. D. (in press). Challenging "scientific" paradigms through sociocultural lens and dialogic methodologies in teacher identity research. In C. Siry, C. Schreiber, R. Gomez Fernandez, and B. Reuter (Eds.) Critical Methodologies for Researching Science Teaching and Learning. Rotterdam, The Netherlands: Sense.

Adams, J. D., Kim, E.-J., \& Das, A. (2020). The Crit-Trans Heuristic for Transforming STEM Education: Youth and Educators as Participants in the World. In S. Steinberg (Ed.) Sage Handbook of Critical Pedagogy (pp. 1497-1507). Sage Publishing. 
Adams, J. D., \& Siry, C. (2020). Living the Authenticity Criteria in STEM Education Research. In K. Otrel-Cass and M. Ryu, Examining Ethics in Contemporary Science Education Research (pp. 143-158). Springer.

Adams, J. D. (2019). WhatsApp with Science? Emergent CrossActionSpaces for Communication and Collaboration Practices in an Urban Science Classroom. In Emergent Practices and Material Conditions in Learning and Teaching with Technologies (pp. 107-125). Springer.

Adams, J. D. (2018). Critical creativity inquiry: Transforming our understandings of and engagements in the world. In: Bryan, L., \& Tobin, K. (Eds.). Critical Issues and Bold Visions for Science Education: The Road Ahead (pp. 157-170). Netherlands: Sense Publishers.

Adams, J. D., \& Gupta, P. (2017). Informal science institutions and learning to teach: An examination of identity, agency and affordances. Journal of Research in Science Teaching, 54(1), 121-138.

Adams, J., Miele, E., \& Powell, W. (2016). City-as-Lab Approach for Urban STEM Teacher Learning and Teaching. In L. Avraamidou and W-M Roth (Eds.) Intersections of Formal and Informal Science, (pp. 189-200). Routledge.

Adams, J. (2007). The historical context of science and education at the American Museum of Natural History. Cultural Studies of Science Education, 2(2), 393-440.

Avraamidou, L. (2014). Studying science teacher identity: Current insights and future research directions. Studies in Science Education, 50(2), 145-179.

Coble, C., Smith, T., \& Berry, B. (2009). The recruitment and retention of science teachers. In A. Collins \& N. Gillespie (Eds.). The Continuum of Secondary Science Teacher Preparation (pp. 1-21). Rotterdam: Sense Publishers.

Darling-Hammond, L., \& Sykes, G. (2003). Wanted: A national teacher supply policy for education: The right way to meet the "Highly Qualified Teacher" challenge. Education Policy Analysis Archives. http://eppa.asu.edu/epaa/vun33/.

Das, A., Strong L., McCullough S., \& Adams J. D. (2020) Developing Political Activity as if the World is on Fire. Journal of Critical Thought and Praxis, 10(1). doi: https://doi .org/10.31274/jctp.11618.

Davies, B.(2006).Subjectification:The relevance of Butler's analysisforeducation. British Journal of Sociology of Education, 27(4), 425-438. D or: 10.1080/01425690600802907.

Davis, E., Petish, D., \& Smithey, J. (2006). Challenges new science teachers face. Review of Educational Research, 79(4), 607-651.

Gupta, P., \& Adams, J. (2010). Museum-University Partnerships for Pre-service Education. In B. Fraser, K. Tobin, \& C. McRobbie (Eds.) Second International Handbook of Science Education (pp. 1147-1162). Kluwer Academic Publishers.

Gupta, P., Adams, J., Keisel, J., \& DeWitt, J. (2010). Examining complexities of schoolmuseum partnerships. Cultural Studies of Science Education, 5, 685-699. 
Hodkinson, P., Biesta, G., \& James, D. (2008). Understanding learning culturally: Overcoming the dualism between social and individual views of learning. Vocations and Learning , 1, 27-47.

Hurtado, S., Newman, C. B., Tran, M. C., \& Chang, M. J. (2010). Improving the rate of success for underrepresented racial minorities in STEM fields: Insights from a national project. New Directions for Institutional Research, 2010(148), 5-15.

Jackson, A. Y., \& Mazzei, L. A. (2011). Thinking with theory in qualitative research: Viewing data across multiple perspectives, Routledge, New York.

Jackson, A. Y. (2001). Multiple Annies: Feminist poststructural theory and the making of a teacher. Journal of teacher Education, 52(5), 386-397.

Korthagen, F., Loughran, J., \& Russell, T. (2006). Developing fundamental principles for teacher education programs and practices. Teaching and Teacher Education, 22, 1020-1041.

Martin, S. (2006). Where practice and theory intersect in the chemistry classroom: Using cogenerative dialogue to identify the critical point in science education. Cultural Studies of Science Education, 1(4), 693-720.

Mazzei, L. A. (2014). Beyond an easy sense: A diffractive analysis. Qualitative inquiry, 2o(6), $742-746$.

Melber, L. M., \& Cox-Peterson, A. M. (2005). Teacher professional development and informal learning environments: Investigating partnerships and possibilities. Journal of Science Teacher Education, 16, 103-120.

Merriam-Webster. (n.d.). Equity. In Merriam-Webster.com dictionary. Retrieved from https://www.merriam-webster.com/dictionary/equity.

Moyer-Packenham, P., Bolyard, A., Kitsantas, A., \& Oh, H. (2008). The assessment of mathematics and science teacher quality. Peabody Journal of Education, 83, 562-591.

Nasir, N., Snyder, C. R., Shah, N., \& Ross, K. M. (2013). Racial storylines and implications for learning. Human Development, 55(5-6), 285-301. doi:10.1159/ooo345318.

National Research Council (2009). Learning science in informal environments: People, places, and pursuits. Committee on Learning Science in Informal Environments. National Academies Press.

Phillips, M., Finkelstein, D., \& Wever-Frerichs, S. (2007). School site to museum floor: How informal science institutions work with schools. International Journal of Science Education, 29(12), 1489-1507.

Schmidt, B. E. (2008). Caribbean Diaspora in the USA:Diversity of Caribbean religions in New York City. Ashgate Publishing, Ltd..

Seiler, G., \& Elmesky, R. (2005). The who, what, where, and how of our urban ethnographic research. In K. Tobin, R. Elmesky \& G. Seiler (Eds.), Improving Urban Science Education: New roles for teachers, students and researchers (pp. 1-20). New York: Rowman \& Littlefield Publishers. 
Sewell, W. H. (1992). A theory of structure: duality, agency, and transformation. American Journal of Sociology, 98, 1-29.

Steinberg, S. R., \& Kincheloe, J. L. (2010). Power, emancipation, and complexity: Employing critical theory. Power and Education, 2(2), 140-151.

Stetsenko, A. (2011). From relational ontology to transformative activist stance on development and learning: Expanding Vygotsky's (CHAT) project. In Marxism and education (pp. 165-192). Palgrave Macmillan, New York.

Strong, L., Adams, J. D., Bellino, M. E., Pieroni, P., Stoops, J., \& Das, A. (2016). Against Neoliberal Enclosure: Using a Critical Transdisciplinary Approach in Science Teaching and Learning. Mind, Culture, and Activity, 23(3), 225-236.

Sue, D. W., Capodilupo, C. M., Torino, G. C., Bucceri, J. M., Holder, A. M. B., Nadal, K. L., \& Esquilin, M. (2007). Racial microaggressions in everyday life: Implications for clinical practice. American Psychologist, 62(4), 271-286.

Syed, M., \& Chemers, M. M. (2011). Ethnic minorities and women in STEM: Casting a wide net to address a persistent social problem. Journal of Social Issues, 67(3), 435-441.

Weedon, C. (2004). Identity and culture: Narratives of difference and belonging: Narratives of difference and belonging. McGraw-Hill Education (UK).

Wilson, S. M., \& Berne, J. (1999). Teacher learning and the acquisition of professional knowledge: an examination of research on contemporary professional development. Review of Research in Education, 24, 173-209. 